\title{
IMAGENS QUE PAIRAM: A FANTASMAGORIA DAS IMAGENS EM CIRCULAÇÃO'
}

\author{
IMAGES THAT HOVER: THE PHANTASMAGORIA OF IMAGES IN \\ CIRCULATION
IMÁGENES QUE PASAN: LA FANTASMAGÓRICA DE LAS IMÁGENES EN CIRCULACIÓN

Ana Paula da Rosa ${ }^{2}$

RESUMO: na midiatização se verifica a ascensão das superfícies que, potencializadas pelos protocolos sociossemiotécnicos, acionam memórias e alteram as noções de tempo e de referência. As imagens são inseridas na circulação midiática tanto por instituições jornalísticas quanto por atores sociais que reelaboram os sentidos, mas preservam a força de imagens anteriores. $\mathrm{O}$ artigo discute a circulação e, especialmente, as reminiscências da imagem do menino sírio Aylan Kurdi, pois a imagem se presentifica em outras fotografias e vídeos de conflitos na região da Síria. Questiona-se: em que medida a fotografia do menino se instala como uma fantasmagoria? Assim, acionamos a análise empírica e os conceitos de "iconologia dos intervalos" e "nachleben" de Warburg (2013), de corporeidade em Kamper (2016), e dos aportes específicos da midiatização.

Palavras-chave: Imagem. Midiatização. Circulação.

ABSTRACT: in mediatization, there is an increase in the surfaces that, potentialized by social/semio/technical protocols, activate memories and change the notions of time and reference. Images are inserted in media circulation by both journalistic institutions and social actors who rework the meanings but preserve the strength of previous images. This article discusses circulation and, especially, the reminiscences of the Syrian boy

\footnotetext{
Trabalho apresentado no GT Comunicação e Cultura do XXVI Encontro Anual da Compós em 2017.

ORCID: 0000-0001-7461-2278. E-mail: anarosa208@yahoo.com.br
} 
Aylan Kurdi's image because that image is present in other photographies and videos of the conflicts in the Syria region. We ask: to what extent does the photograph of the boy set itself like a phantasmagoria? Thus, we have used empirical analysis and the concepts of "intervals iconology" and "nachleben" by Warburg (2013), corporeity in Kamper (2016), and the specific mediatization theoretical contributions.

Keywords: Image. Mediatization. Circulation.

RESUMEN - En la mediatización se verifica el ascenso de las superficies que, potenciadas por los protocolos sociossemiotecnicos, accionan memorias y alteran las nociones de tiempo y de referencia. Las imágenes se insertan en la circulación mediática tanto por instituciones periodísticas como por actores sociales que reelaboran los sentidos, pero preservan la fuerza de imágenes anteriores. El artículo discute la circulación y, especialmente, las reminiscencias de la imagen del niño sirio Aylan Kurdi, pues la imagen se presentira en otras fotografías y videos de conflictos en la región de Siria. Se pregunta: ¿en qué medida la fotografía del niño se instala como una fantasmagórica? Así, accionamos el análisis empírico y los conceptos de "iconología de los intervalos" y "nachleben" de Warburg (2013), de corporeidad en Kamper (2016), y de los aportes específicos de la mediatización.

Palabras clave: Imagen. Mediatización. Circulación.

\section{Apontamentos iniciais}

A palavra imagem traz consigo, quase que de modo inerente, a sensação de incompletude. Tal sensação é manifesta na dificuldade de compreensão do significado e da importância das imagens no processo de construção social. As inúmeras tentativas de definição do que é uma imagem não dão conta do seu papel ou porque se prendem ao aspecto da captura do objeto, portanto à concepção de reprodução óptica, ou porque se prolongam em um debate sobre o real. No entanto, há um traço que nos parece fundamental, a imagem como acionadora da cultura, acolhida e acolhedora, presente e futuro na memória coletiva. Essa característica da imagem que transforma a cultura pode ser vista na ampliação da oferta de superfícies e na reconfiguração da história em um elemento dinâmico.

Quanto às superfícies, para Flusser (2007), essas adquirem cada vez mais importância, passam a nos circundar nos meios de comunicação como a televisão e a internet. Porém, não são um fenômeno novo, já que podemos considerar as próprias pinturas rupestres como superfícies. A diferença central é que antes do século XX não tínhamos uma gama tão intensa de imagens, o próprio processo 
de produção era demorado e menos acessível. Hoje, as imagens-superfícies estão no nosso entorno a ponto de nos fazermos superfícies. Conforme Flusser (2007, p. 105-104), "não se trata mais apenas do problema da adequação do pensamento à coisa, mas do pensamento expresso em superfícies à coisa, de um lado, e do pensamento expresso em linhas de outro". Esta problemática implica na compreensão de que as linhas, portanto uma única dimensão, pretendem chegar a algum lugar, podemos segui-las simplesmente para encontrar o sentido. As superfícies, duas dimensões, já estão em outro lugar e nos permitem, por recomposição, um percurso nos rastros, mostrar como chegaram lá. Ou seja, trata-se de uma transição temporal.

Essa transição incide na reconfiguração da história. Se considerarmos a história como feita de linhas, de um processo que segue um curso, percebemos aí um modelo que não parece mais suficiente para dar conta das superfícies. Sua forma dinâmica, mesmo quando não se trata de imagens em movimento, leva ao rompimento dessa linearidade, implicando em um "estar no mundo" pós-histórico, isto é, onde as superfícies consomem as linhas, alterando a percepção de tempo. Assim, Hans Belting (2006, p. 259) trata da pós-história como "a representação de viver numa época posterior à história, e nesse caso de poder aplicar com coerência o conceito de história apenas ao passado". Isto é, a defesa do autor para o fim da história da arte está ancorada no fato de que a linearidade está rompida e que o presente e o passado se fundem, se reatualizam e se imbricam constantemente. Belting (2006, p. 275) ressalta que o novo já não está nas ideias a serem apresentadas, mas na escolha do meio, na técnica.

Surge aí uma vinculação importante com o conceito de midiatização, marcado pela configuração de uma nova ambiência (GOMES, 2004) que transforma o modo de ser no mundo e, consequentemente, as práticas sociais a partir de protocolos sociossemiotécnicos. Nesta ambiência, produtores e receptores atuam como cogestores da cultura, implicando em novos modos de pensar, ver, produzir e compartilhar imagens. Ampliam-se, portanto, as possibilidades de superfícies e tende-se ao fim das linearidades ${ }^{3}$ tanto no processo comunicativo em si como na concepção de história. Entendemos o conceito de midiatização neste trabalho, a partir de Ferreira (2007), como a articulação entre os processos sociais e os midiáticos que se realiza no âmbito dos dispositivos midiáticos. Os dispositivos são pontos de intersecção e, no caso das imagens, são fundamentais, uma vez

\footnotetext{
3 Isso não significa que o fim das linearidades se traduza como uma redução do espaço da escrita, mas da aceitação de que mesmo a escrita é revista, repensada.
} 
que essas são produzidas, compartilhadas e replicadas em espaços vinculados às instituições midiáticas, mas também de atores sociais.

Desse modo, o momento atual é parte de um processo evolutivo de midiatização4, onde as lógicas midiáticas não estão mais restritas ao espaço dos meios de comunicação, mas integram a cultura. O domínio das lógicas midiáticas confirma o posicionamento de Belting (2006) quanto ao espaço da técnica que implica em outro modus operandi social. Isso vale, por exemplo, para as apropriações imagéticas, em especial as jornalísticas, que parecem ter uma ampliação conforme os níveis diferenciados de conhecimento e as possibilidades de acesso às tecnologias.

Ante o exposto, partimos, neste texto, de um cenário de midiatização em processo, bem como de uma ascensão das superfícies que, quando consolidadas em imagens, convocam estruturas simbólicas, acionam memórias e modificam duas noções centrais: a de tempo e a de referência. Em nossa visada, as imagens são inseridas no processo de circulação seja por instituições jornalísticas como por atores sociais que reelaboram os sentidos, mas preservam a força de imagens anteriores. Assim, nossa hipótese é a de que a circulação implica em circularidade (KLEIN; ROSA, 2006) e, essencialmente, em uma relação de atribuição de valor. Este artigo visa discutir a circulação e, especialmente, as reminiscências da imagem do menino sírio Aylan Kurdi, encontrado morto em uma praia na Turquia, em setembro de 2015. Questiona-se: em que medida a fotografia de Aylan Kurdi se instala como uma fantasmagoria? E que relações são produzidas na circulação entre as figuras?

\section{O abismo das imagens devoradoras de imagens}

Mise en abyme é um termo utilizado para indicar uma narrativa em abismo ou aquela estrutura visual formada por repetições dos elementos que a compõem em diferentes dimensões. Trata-se de uma visão de profundidade, isto é, do abismo. O título desse item, voltado à constituição do caso de pesquisa e do campo de observação, não se refere exatamente a essa perspectiva, mas a noção de abismo reside no fato de que as imagens aqui analisadas prolongam a referência, vemos uma dentro da outra ou somos levados a ver.

\footnotetext{
4 José Luiz Braga considera o processo em vias de midiatização, uma vez que embora consolidado, ainda não está finalizado, nem tampouco se pode saber quais extensões e derivações estão por vir. 5 Anuschka Lemos (2007) trata dessa perspectiva em sua dissertação de mestrado intitulada "Um mergulho no abismo: estratégias comunicacionais da imagem fotográfica".
} 
O caso desse trabalho é configurado a partir da produção/circulação da fotografia do menino sírio Aylan Kurdi, produzida pela fotógrafa Nulifer Demir, em 2015. O corpo da criança de apenas três anos foi encontrado em uma praia, na Turquia, após o barco em que estava com a família naufragar. A imagem do registro do desfecho da travessia rumo à Europa transformou-se na imagem mais vista do mundo em poucos segundos. Além do Trending Topics do Twitter, a fotografia resultou em mais de 500 mil páginas sobre o tema, grande parte delas com a replicação da imagem. A fotografia da criança (Figura 1) transformou-se em símbolo da tragédia Síria efetivamente a partir do momento em que passou a restringir o acesso de outras imagens ou a vincular-se como um emblema ou decalque sobre outros vídeos e fotografias que remetam à situação da crise imigratória, mesmo quando a veracidade da imagem é posta à prova ou questionada. Não são poucas as produções que tentam comprovar a montagem da cena, inclusive com deslocamento do corpo a fim de "criar" um cenário mais apelativo.

Figura 1 - Fotografia reproduzida em múltiplos dispositivos

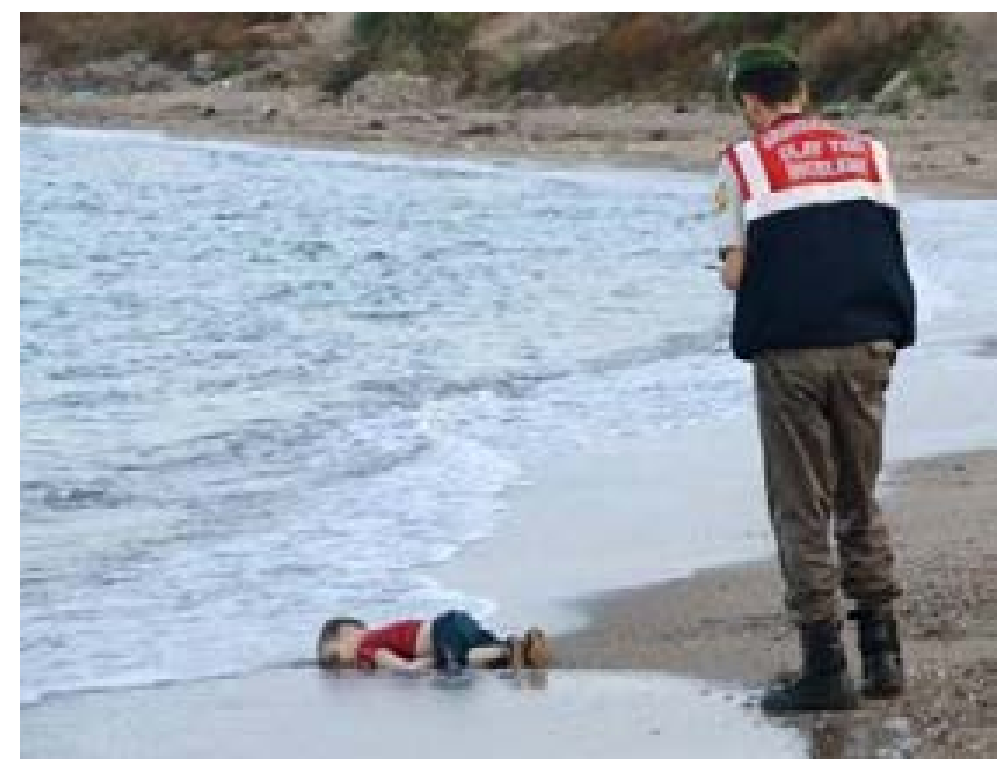

Fonte: Nilufer Demir/Reuters.

Esta imagem foi posta em circulação a partir do momento em que foi disponibilizada na web, sendo inserida em inúmeros dispositivos de atores sociais midiatizados e de instituições jornalísticas. Além da replicação literal da fotografia, tivemos operações de montagens fotográficas, movimentos de aproximação e enquadramento em close, derivações em ilustrações, charges, vídeos e até mesmo 
performances em protesto. Isso implica dizer que tanto a produção jornalística como a amadora se deram em fluxos, agenciando novos circuitos interacionais (BRAGA, 2012). A imagem noticiosa, porém, poderia ter o seu tempo de inscrições e de reinscrições encerrado, uma vez que os conflitos perduram e a crise imigratória gera novas imagens e personagens. Este é o ponto central, a fotografia de Aylan Kurdi se estende para além da durabilidade noticiosa do fato ou do acontecimento, vinculando-se ou sendo vinculada em outras imagens subsequentes.

Deste modo, nosso campo de observação e configuração do caso ${ }^{6}$ se intensifica. Posteriormente à ampla produção social sobre a imagem de Aylan Kurdi, outra fotografia foi publicada em jornais e em vários espaços na web tendo a crise política e social na Síria como tema. Versa-se, aqui, sobre a imagem de Omran Daqneesh, cinco anos, localizado em Aleppo entre os destroços de um prédio, em agosto de 2016. A fotografia do menino com o rosto coberto de sangue e em estado de choque (Figura 2) também se proliferou em redes sociais tão logo foi disponibilizada pela agência Reuters, embora tenha sido produzida pelo fotógrafo Mahmoud Raslan para o grupo opositor Aleppo Media Center (AMC).

Em entrevista disponibilizada no Facebook da ONG The Syria Campaign e reproduzida pelo G1 em 19 de agosto de 2016 o autor da imagem ressalta que estava produzindo uma filmagem do resgate realizado pela defesa civil do local, quando ao constatar o estado de choque do menino optou por produzir a foto. Destaca Raslan, que chorou diante da cena e que espera "que todas as fotos de crianças e ataques na Síria viralizem para que o mundo saiba como é a vida aqui". A dimensão da circulação da fotografia, no entanto, certamente foi além do que o produtor da imagem poderia supor. Atrelada à imagem de Aylan Kurdi, Daqneesh em choque tornou-se um novo rosto sobre a guerra na Síria. A imagem do menino foi inserida em dispositivos midiáticos de diversas instituições jornalísticas em todo o mundo (de CNN, BBC aos jornais e telejornais brasileiros) e também em espaços de atores sociais midiatizados que inclusive promoveram colagens e sobreposições com a fotografia de Kurdi.

\footnotetext{
6 Adotamos nesse artigo uma metodologia de construção do caso que vem sendo organizada e discutida no âmbito do PPG em Ciências da Comunicação, na Unisinos.
} 
Figura 2 - Fotografia produzida em resgate realizado na Síria

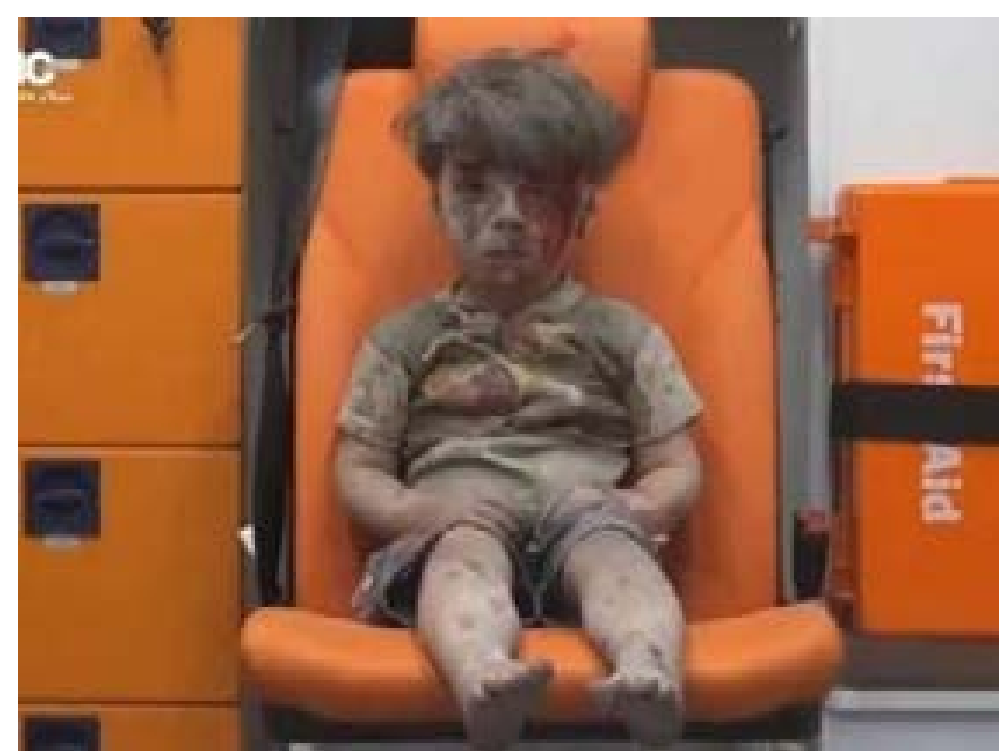

Fonte: Raslan para a Reuters.

São mais de 370 mil páginas sobre Daqneesh no site de buscas Google e diversas produções amadoras ou de chargistas. Pouco mais de dois meses depois, um "novo rosto" foi apontado como o substituto de Omran Daqneesh, o da menina Aya, de 8 anos. "Primeiro foi Alan Kurdi, cujo corpinho de 3 anos foi encontrado sem vida no Mediterrâneo. Depois Omran Daqneesh, em choque, sentado em uma ambulância, coberto de sangue e poeira após sobreviver a um bombardeio em Aleppo. E agora uma menina se transformou no novo rosto da tragédia síria." O texto é o lead de notícia do portal Yahoo. ${ }^{7}$ As imagens de Aya ferida (Figura 3), perdida e em busca do pai, foram divulgadas na internet pelo grupo ativista pró-oposição Talbiseh Media Center.

Disponível em: https://br.noticias.yahoo.com/aya-a-menina-que-se-transformou-no-novo-rosto-da-101136692.html. 
Figura 3 - Aya antes e depois do bombardeio
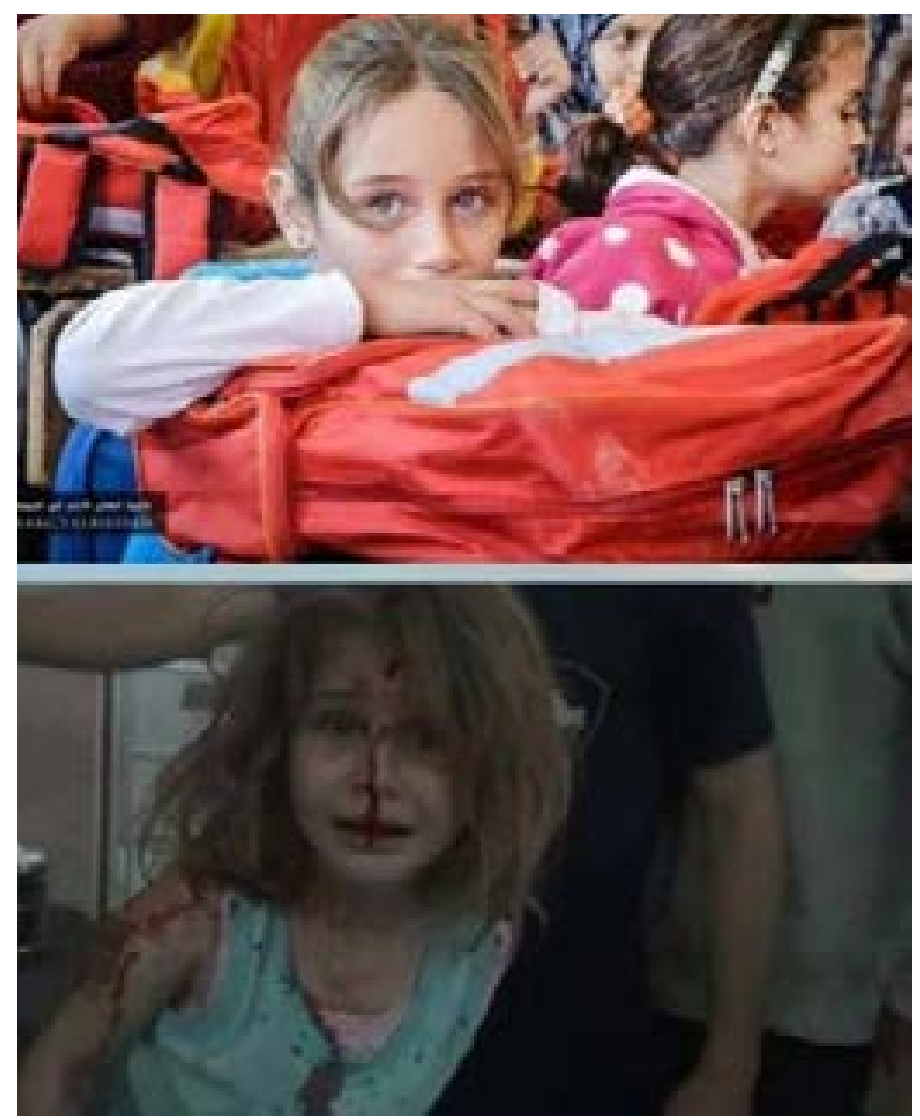

Fonte: Talbiseh Media Center.

Destaca-se que a situação da menina Aya em Aleppo é vivida por milhares de pessoas. Segundo dados divulgados pelo grupo Talbiseh Media Center, em 2016 foram mais de 350 mil mortos e milhões de pessoas deslocadas ou em movimento de imigração. As elaborações discursivas noticiosas sobre a imagem de Aya agregam uma conotação de apelo ao emocional do leitor, o que corrobora para a ligação dessa imagem com a de Aylan Kurdi. O jornal online português Ptjornal ${ }^{8}$ criou uma manchete que faz ligação com imagens mais profundas do social, vinculadas à religiosidade, por exemplo. $O$ título "A menina síria que chora sangue e chama pelo pai" remete às inúmeras estátuas de Santas que foram investigadas por fenômenos como o verter lágrimas de sangue. Há aí uma implícita noção de que Aya (e consequentemente as outras crianças mortas em casos anteriores) são anjos ou possuem relação divina. $O$ jornal ainda alerta que "o vídeo pode perturbar pessoas sensíveis". Ou seja, a imagem que não devia ser

8 Disponível em: http://ptjornal.com/menina-siria-chora-sangue-chama-pai- 111610. 
vista, será repetida milhares de vezes, isto porque o desejo de não ver é subjugado pelo desejo de ver e repetir, o que já tratamos em artigo anterior sobre a noção de fagia social9.

Dentre as inúmeras replicações da imagem podemos destacar o Facebook do grupo Syrian Revolution Talbisah $7^{10}$ onde Aya aparece antes e depois do ocorrido como na Figura 3, anteriormente indicada, em uma montagem comparativa. Destaca-se que mais de 120 pessoas "curtiram" essa postagem e pelo menos 40 compartilharam. Os números podem parecer baixos, no entanto, trata-se de apenas uma das páginas que trouxeram o rosto de Aya e que exemplifica a capilaridade passível de ser obtida a partir de uma inscrição na circulação. Outra publicação, a portuguesa, Mundo ao minuto"1 aponta claramente a relação entre as três imagens anteriormente apresentadas.

Há mais uma criança cujo rosto se está a tornar um dos símbolos das vítimas da guerra que há mais de cinco anos divide e devasta a Síria. Depois de Aylan, o menino refugiado sírio de três anos que morreu afogado e cujo corpo deu à costa na Turquia, e do rosto de choque do pequeno Omran, de cinco anos, vítima de bombardeamentos em Aleppo, a CNN conta-nos a história de Aya, uma menina de oito anos da cidade síria de Talbiseh. ${ }^{2}$

O recorte da notícia evidencia que a ausência física da imagem não interfere na noção de abismo aqui tratada ou, na devoração das imagens anteriores, uma vez que a presença discursiva aciona o imaginário coletivo que "reativa" as imagens primeiras. E, por fim, fechando o campo de observação deste artigo, acrescentamos a imagem de um bebê encontrado morto nas margens do rio Naf, em Mianmar. A foto de Mohammed Shohayet, de 16 meses, mostra o menino caído na lama. A fotografia (Figura 4) foi disponibilizada em 4 de janeiro de 2017 e divulgada logo em seguida nas redes sociais, mas também em dispositivos jornalísticos.

\footnotetext{
9 A ideia de fagia social foi apresentada por ROSA (2016) como um dos movimentos de circulação intermidiática e que se traduz pelo consumo exacerbado de determinadas imagens por parte de atores sociais e instituições jornalísticas.

10 Disponível em: https://www.facebook.com/T.M.C.2O11/photos/a.610922272357615.1073741828.61092068 9024440/1045089445607560/?type=3\&theater..

"Disponível em: https://www.noticiasaominuto.com/mundo.

12 Disponível em: https://www.noticiasaominuto.com/mundo.
} 
Figura 4 - Bebê de 16 meses morre em travessia do rio Naf

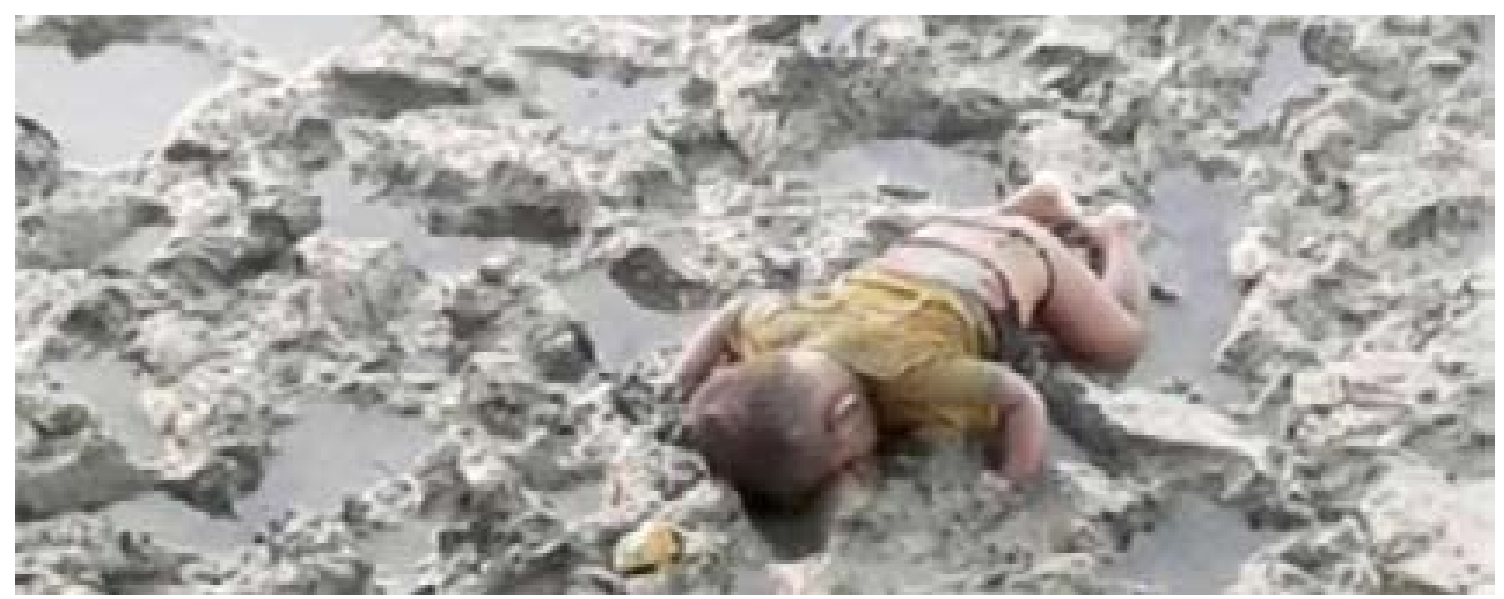

Fonte: Facebook de Ro Sadak.

Assim como no caso de Aylan Kurdi, a família da criança foi vitimada na tentativa de fuga para Bangladesh, sobrevivendo apenas o pai que, aliás, é a figura central para a circulação dessa imagem. Em diversas publicações a fonte da fotografia é atribuída a Ro Sadak, perfil de um usuário de Facebook de Mianmar. No entanto, em entrevista à CNN, o pai, Zafor Alam, informou que a imagem foi divulgada por ele neste ano, uma vez que o fato teria ocorrido no início de dezembro de 2016. O jornal Thestar.com vinculado ao Toronto Star publicou uma entrevista com o pai do menino que foi reproduzida, na íntegra, no Facebook de Ro Sadak, que subsidiou inúmeros dispositivos midiáticos jornalísticos ou de atores sociais. Na reportagem, Zafor Alam ressalta que ele recebeu a fotografia um dia após o ocorrido e que resolveu mostrá-la ao mundo para que, assim como a imagem de Kurdi, "a foto de seu filho possa galvanizar o mundo para resolver a crise Rohingya". Isto é, a foto de Kurdi funciona como espécie de modelo para inscrições futuras. Destaca-se também que a entrevista ao Thestar é baseada em entrevista anterior concedida à $\mathrm{CNN}$, o que demonstra também o processo de fagia midiática (ROSA, 2016a), já que um dispositivo jornalístico consome e reelabora o discurso do anterior, levando o sentido adiante.

Na busca pela origem da fotografia verifica-se que a primeira publicação é do canal de TV e portal da web chamado Rohingya Vision'3, que publicou a imagem em 5 de dezembro de 2016, portanto um mês antes de sua circulação no Brasil e nos Estados Unidos. A RVision é um canal de mídia independente, fundado em 2012, e que distribui notícias em diversos idiomas. A partir de vídeos e fotografias disponi-

13 Disponível em: http://www.rvisiontv.com/dozen-killed-as-burmese-border-guards-open-fire-on-rohingya-boats. 
bilizadas no site e no YouTube por essa instituição midiática independente, ocorreu uma reverberação em outros espaços promovendo uma circulação tardia. Localizamse no portal de buscas Google mais de 800 mil páginas sobre o tema, muitas delas questionando a veracidade da imagem intitulada como o "Rohingya Alan Kurdi".

Após a apresentação desse conjunto de imagens e acontecimentos podemos de fato delimitar o nosso caso de pesquisa. Não se trata, portanto, apenas da imagem de Aylan Kurdi, mas de sua permanência em circulação, onde é valorizada a cada nova publicação em dispositivos midiáticos, mesmo quando é apenas referida. Observa-se que nos quatro exemplos mencionados temos alguns aspectos centrais como: a) fonte de acesso às imagens; b) lógicas de circulação intra e intermidiática; c) a referência à imagem primeira que adere aos acontecimentos posteriores; d) diferenças estéticas, mas semelhanças contextuais; e) evidência do critério de noticiabilidade "choque" e, por fim, f) a noção da imagem como fantasmagoria atribuindo uma "vida póstuma" às imagens.

Quanto à fonte de acesso às imagens, temos nos quatro exemplos fotógrafos profissionais que produzem as imagens para suas instituições de origem, geralmente locais. Essas imagens são vinculadas a grupos ativistas de mídia independente que as colocam em circuito, principalmente, quando as disponibilizam para agências internacionais de notícia que pulverizam sua publicação. Isso incide na questão da circulação intramidiática, ou seja, dentro do próprio dispositivo de ativistas como portais, por exemplo, como também a lógica da circulação intermidiática, onde os ecos se proliferam em dispositivos de atores sociais via compartilhamento e também em espaços jornalísticos.

Quanto à referência da imagem primeira tem-se neste conjunto a de Aylan Kurdi, que adere aos acontecimentos, uma vez que se tornou autorreferencial. As diferenças estéticas e de composição mostram que apenas as Figuras 1 e 4 são realmente parecidas, pois tratam do afogamento de crianças, mas 2 e 3 se vinculam porque incluem crianças feridas em conflitos que tratam direta ou indiretamente da Síria. Plasticamente são fotografias distintas tanto pelo ângulo, pela luminosidade, mas têm em comum o aspecto temático e a proximidade, pois todos os registros configuram planos de close ou que destacam determinando elemento na cena, ressaltando o olhar da criança direcionado para a câmera. 0 critério de noticiabilidade e, consequentemente, de circularidade está no fato de que todas as situações envolvem crianças, apresentam o horror da guerra ou da crise imigratória. Além disso, tais imagens servem como uma espécie de apelo e foto-choque, porque acionam imaginários individuais e coletivos como a relação pais e filhos, a percepção da inocência infantil, a configuração do anjo. Tratam- 
se de metáforas visuais que carregam a característica do registro, portanto não são "apenas" montagens, mas sua relação de referência se dá percorrendo a ideia de abismo, isto é, uma imagem permite ver a outra, em atualizações múltiplas. Tais atualizações via circulação levam ao indício de fantasmagorias de corpos transformados em imagens.

\section{A circulação como valor nas interações: atualizações e convocações em fluxos}

O conceito de circulação é, atualmente, um dos mais caros às discussões relacionadas à midiatização. Não porque seja um termo novo, mas porque a sua centralidade se acentua no processo comunicativo quando entendemos que a relação entre as lógicas ou gramáticas de produção e reconhecimento, cada vez mais, se perpassam, se atravessam. Isto significa que o espaço entre a produção e o reconhecimento (VERÓN, 2004; 2013), anteriormente denominado de intervalo, torna-se a instância operadora da comunicação, uma vez que a produção de sentido é ali efetivada. Obviamente que essa noção de circulação como espaço pode levar a uma errada visão de que tratamos de um local físico, único; ao contrário, em nossa perspectiva a circulação é esse momento invisível, que se identifica seguindo os rastros das materialidades, e que nos permite entender $o$ sentido em movimento e dinamicidade, portanto em espaços múltiplos e diferidos. No que diz respeito às imagens, essas são disponibilizadas para a circulação, produzidas e pensadas exatamente com esse propósito de midiatização. Assim, temos imagens ofertadas, elaboradas, reelaboradas, replicadas, regendo novos significados ou preservando uma espécie de sombra, que se acopla pelo duplo processo de circulação e de circularidade ${ }^{14}$.

Decorre daí um trabalho intenso de valorização entre as instâncias comunicativas que se cruzam em um jogo interacional a partir do acesso e dos usos dos dispositivos. Para Fausto Neto (2013, p. 47), "a técnica, em de vez de produzir ampliação das distâncias entre produtores e receptores, trata de encurtá-las, reunindo-as agora na forma de contatos". Cada contato ou acoplamento demanda um esforço de produção de sentido, ou seja, a imagem inserida no portal de Mianmar que se liga ao Facebook de um jovem ativista e que é acoplada a

\footnotetext{
14 Há uma diferença importante entre circulação e circularidade. A circulação está voltada para a processualidade interacional, que implica em novas camadas de sentido. Já na circularidade temos objetos que efetivamente são repetidos, aparecem, reaparecem e se instalam. A circularidade envolve o próprio processo do olhar. Temos, em nossos casos de análise, uma circularidade do tempo e das imagens no tempo.
} 
publicações brasileiras, como no G1, exemplifica uma cadeia de produções, sobreposições e contatos que levam o sentido adiante. A partir disso, nossa percepção é a de que, apesar das divergências e defasagens entre as instâncias em jogo, se percebe uma configuração de elos por meio de práticas tecnodiscursivas. Essas vinculações não implicam em um olhar do olho único's, mas revelam elementos de pertinência social que são partilhados tanto pela produção como pelo reconhecimento derivando em circuitos (BRAGA, 2012).

As imagens que compõem o nosso campo podem ser entendidas como circuitos interacionais, pois a cada nova publicação ocorrem repercussões, reelaborações, interpretações diversas que resultam em tensões e, certamente, em ratificações da força da imagem. Por esse ângulo, sustentamos a hipótese de que a circulação se constitui como uma relação de atribuição de valor. Isso é verificável na criação dos circuitos, pois apenas as imagens percebidas e tomadas como relevantes passam a permanecer em circulação, o que demonstra que a cada nova inserção, tais imagens são acrescidas de valor, potencializadas. Em parte, isso explica o porquê de algumas imagens desaparecerem, ainda que estejam disponíveis nos baús de memória da web. A força de pregnância (ROSA, 2015) de determinadas imagens, postas a circular e que assumem um aspecto de circularidade, acaba por determinar certo poder de fixação.

Nessa perspectiva, o papel dos dispositivos midiáticos também passa a ser amplificado, pois o jogo pela constituição do visível se realiza no intercruzamento da produção e do reconhecimento que possuem plenas condições de desenvolver práticas enunciativas de visibilidade. Dessa maneira, temos a fotografia de Aylan Kurdi que aparece em 2015, é inserida em dispositivos jornalísticos e de atores sociais, ampliando as formas de acesso e reingresso da imagem na circulação. Tanto discursos de crítica como de adesão endossam a imagem primeira, mesmo quando é retomada em 2017 para contextualizar outra imagem. Esse percurso entre aparecimento - valorização nas interações - reiteração - reaparecimento suscita um processo de autonomização da imagem em relação ao acontecimento, pois as remissões feitas estão voltadas mais à força imagética do que ao fato em si.

Não se trata, portanto, da crise da imigração ou dos conflitos sírios, mas da transformação de imagens valorizadas na circulação em decalques ou em imagens-totens (ROSA, 2012). Esse conceito ancorado nas formulações de Cassirer e

15 Consideramos que no processo de midiatização não há mais um olho único, apenas um direcionamento, pois a produção de sentido é infinita. Se há casos de uma unificação discursiva ou de sentido esta é criada coletivamente. 
de Durkheim de totemismo, dá conta de imagens que convocam um laço profundo do social, acionando o imaginário coletivo; ao mesmo tempo em que implica em restrições ao acesso de novas imagens e à interpretação, pois tais produtos audiovisuais se configuram como barreiras. As imagens-totens são consolidadas pelo processo de circulação intra e intermidiática (FERREIRA; ROSA, 2011) que é fomentado tanto por atores sociais como por instituições jornalísticas. Ainda que ocorram tentativas de ruptura, ingresso de novas imagens e sentidos, tais ações tendem a ser rechaçadas socialmente, pois a imagem primeira é transcendente. Questiona-se: seria fantasmagórica?

\section{Da imagem do corpo à vida póstuma das imagens}

Considerando que a midiatização é em essência a complexificação das relações sociais e, consequentemente, da produção de sentido derivada, nosso olhar se volta aqui para a questão dessa imagem que circula e se eterniza nos meios de comunicação e para além deles. Em um primeiro momento, nos chama a atenção o fato de que as imagens do corpus desse artigo envolvem um corpo: um corpo morto, um corpo-rosto. Tais imagens envolvem o corpo de quem observa e age sobre as fotografias, potencializando os sentidos da distância como a visão e incitando uma compulsão às imagens, pois já não basta ver, é preciso levar adiante o visto. Dietmar Kamper (2016, p. 71) destaca que "tudo o que não é visível é tido como inútil e descartado antes mesmo de entrar no jogo. Por sua vez a imagem apropriada ao olhar, com a participação daquele que é olhado, pode ser formada ativamente nas repetidas encenações de uma vida toda". Assim, estamos sempre sendo provocados a consumir e produzir imagens, a nos transformar em superfícies. Em nome de uma participação social, potencializada pelo acesso aos dispositivos midiáticos, ficar alheio às imagens sem produzir novos circuitos parece algo impensável. Kamper já alertava para a perda da corporeidade multidimensional em função da conformação à superfície.

E o que dizer da imagem do corpo que nos lembra a nossa corporeidade? Ao ver a fotografia de Kurdi morto ou do bebê em Mianmar somos forçados a lembrar do nosso próprio corpo e de sua falibilidade. Porém, é a imagem que substitui o corpo que permanece em circulação. Kamper (2016, p. 74) ressalta que "o homem é literalmente um produtor em pânico de imagens. Porém, sequer desconfia que essa tendência, capciosamente, se transformou numa sutil mortificação dos humanos e das coisas do mundo". Essa mortificação é evidenciada de um lado pelo sentir mediado, portanto, à distância e, de outro, pela fascinação de imagens de 
cadáveres. O caso de pesquisa deste artigo trata de duas fotografias que retratam a morte e de duas que alertam para o horizonte (ou iminência) da morte. Trata- se, então, de uma valorização do corpo morto em detrimento do corpo vivo que se concretiza tanto no jornalismo como nas produções dos atores sociais midiatizados, já que a realidade parece ser tecida apenas pelas imagens.

A constante produção de circuitos interacionais que colocam as imagens em um fluxo adiante implica em um duplo movimento: a extensão do imaginário ${ }^{16}$ para fora do corpo, para depois retrai-lo, abastecendo-o de imagens já vistas. Esses circuitos são baseados na rememoração, uma vez que os fluxos são constituídos de imagens repetidas e autonomizadas, mas que podem apresentar sentidos outros. Como ressalta Kamper (2016), caberá às máquinas repetidoras do tempo o domínio das lembranças que, cada dia mais, se tornarão testemunhas mudas de um passado. Mas o que estamos testemunhando com o movimento de retrospectiva ou de abismo das imagens? Talvez a resposta seja o início para a compreensão do problema deste artigo que se refere à possibilidade da instalação da fotografia como uma fantasmagoria ${ }^{17}$. Um primeiro passo nesse sentido talvez seja a noção de sombras.

O termo imagem, bild no antigo alemão, carrega a ideia de sombra como uma de suas facetas. A sombra pode ser entendida como um espectro que se vincula às imagens. Entendemos aqui essa noção como a possibilidade de uma espécie de sombra que, mesmo na ausência da imagem de Kurdi, evidencia a sua presença. Kamper (2016, p. 102) explica que não há como o original sobreviver sem a cópia, e nem mesmo a cópia tem condições de se perpetuar sem transformações do sentido, pois as novas inscrições na circulação transformam a ambos.

Contudo, essa ideia de sombra, de espectro, nos permite verificar que os intervalos de inscrição das imagens na circulação também são importantes para a compreensão do processo. Aby Warburg, autor que pensou metodologicamente a "iconologia dos intervalos", ancora o conceito não na significação das figuras, mas nas relações que estas mantêm entre si. O Atlas Mnemosyne ${ }^{18}$ segue essa

\footnotetext{
16 Entendemos o imaginário na acepção de Gilbert Durand (1993) como um repertório iconográfico individual que é abastecido de imagens interiores (nunca materializadas e representadas) e de imagens exteriores, como as fotográficas. Kamper fala em órbita do imaginário, referindo-se às ruínas da humanidade (desde a religião à técnica) que resulta num "caldeirão pós-histórico de estratégias ligadas à realidade e à aparência".

17 Quando nos referimos à expressão fantasmagoria entendemos a imagem que é evocada por outras imagens como uma espécie de fantasma. No entanto, outros autores tratam deste termo, assim como o faz Erick Felinto (2006). Para o autor há uma associação entre tecnologias e o mundo sobrenatural, destacando experiências óticas e audiovisuais como, por exemplo, a fotografia espírita.

18 É um atlas de imagens que ficou incompleto em função da morte de Warburg em 1929. Trata-se de painéis de tecido com justaposições de fotografias, selos, obras de arte, materialidades múltiplas onde imagens
} 
formulação. Transpondo para o momento atual essa perspectiva, podemos pensar que as imagens midiatizadas também se prologam nos intervalos, ou seja, há relações perceptíveis entre fotografias, vídeos e imagens arraigadas na cultura. Michaud (2013, p. 296) destaca que o álbum de imagens de Warburg é "o lugar no qual é possível devolver às figuras arcaicas sedimentadas na cultura moderna a energia expressiva original e no qual a ressurgência pode tomar forma". No caso aqui analisado também identificamos uma ressurgência não apenas da imagem produzida em 2015, mas de outras imagens que tratam de crianças e conflitos, de foto-choques e mesmo da noção que o próprio Warburg identificou na tribo dos índios Pueblos da América do Norte quando menciona que um item essencial na dança indígena é uma árvore que representa a pureza da alma das crianças ${ }^{19}$.

Estamos, então, diante de sequências descontínuas, de intervalos no tempo que não implicam em apagamentos, mas no reaparecimento em potência. Como compreender esse intervalo se não como parte da própria circulação que afeta o fazer social? Não são apenas artistas que acionam imagens anteriores, mas é a própria sociedade que convoca imagens já vistas. Como ressalta Michaud (2013) mnemosyne para Warburg era "uma história de fantasmas para gente grande" e em que medida a evocação de imagens anteriores no cenário da midiatização não se traduz como a instalação de fantasmagorias? Em nossa visada, imagens aparentemente mortas, com um tempo determinado, são reatualizadas em novas inscrições, instaurando imagens que pairam. Destaca-se que essas inscrições não são unilaterais, já que pela disseminação dos dispositivos é possível que produção e reconhecimento se hibridizem, como já mencionado anteriormente.

Nesse sentido, Warburg cunhou a expressão nachleben ou vida póstuma em estudo sobre a antiguidade e as obras de arte. Waizbort (2015, p. 10) argumenta que o termo nachleben considera que a imagem permanece viva e assombrando épocas posteriores, trata- se de uma morta-viva, que pode ser percebida de modo explícito ou em uma sutil referência. Ou seja, a imagem se manifesta com diferentes modalidades de presença. Ao discutir o nascimento de Vênus e a obra Primavera de Sandro Botticelli, Warburg identifica relações de dependência entre a poesia, a pintura, em especial a arte da antiguidade, e outras formas de produção imagética. Warburg refere-se (2015, p. 52) à necessidade de buscar uma "influência" dos modelos antigos na representação dos movimentos, por

compõem uma paisagem e refletem imbricamentos, inclusive, para além do que já foi discutido em termos de história da arte.

19 Esta passagem pode ser lida no $5 .{ }^{\circ}$ capítulo do livro de Warburg (2015). 
exemplo. Isto é, "o inspirador não sugeria o tema a ser imitado, apenas facilitava a expressão do mesmo" (WARBURG, 2015, p. 67).

Ao apresentar a sua tese, o autor considera que "a imagem mnêmica que apercebe uma impressão nova em situações dinâmicas gerais é posteriormente projetada de forma inconsciente na obra de arte como um esboço idealizador". Em nota, como um dos registros feito pelo próprio autor em sua versão, Warburg (2015, p. 86) faz uma correção: "tudo errado, pois não se trata de imagens mnêmicas inconscientes, mas de substituição consciente, com o desejo de acentuar as formas individuais". Podemos dizer, assim, que a imagem de Kurdi que ressurge na imagem do bebê de Mianmar não é somente uma imagem mnêmica inconsciente, mas um ato consciente para acentuar determinados aspectos, bem como para fixar determinadas crenças. No entanto, surge um questionamento importante: como a incorporação de elementos ou imagens anteriores em obras posteriores ressignifica o original? Os sentidos mais antigos são preservados? Entendemos que a única maneira de refletir sobre isso é observar as transformações sofridas no tempo.

Conforme Waizbort (2015, p. 11), Warburg desenvolve "a noção de engrama, uma forma da memória social e coletiva. Ele se enraíza em experiências e comoções muito intensas, que penetram na subjetividade e permanecem armazenadas, podendo afluir posteriormente". Assim a ideia de nachleben se intensifica, pois a possibilidade de reaparição está vinculada ao que está armazenado na memória, que é ativada em situações particulares e frequentemente pela ação das instituições jornalísticas e dos atores sociais.

\begin{abstract}
A nachleben circunscreve essa metamorfose, que implica plasticidade, maleabilidade, mudança das formas. O que só ocorre porque as formas são forças: por trás de cada uma pulsam forças ativas, reativas, fortes, fracas, dominantes ou dominadas. Ademais, outro processo ocorre em paralelo: o olhar sobre as formas e sentidos também se transforma ao longo do tempo e do espaço, alterando a relação do sujeito com as formas, ou seja, também por esse lado chegamos a um processo de transformação das formas... a vida póstuma" no fundo é uma complexa dinâmica de forças" (WAIZBORT, 2015, p. 12).
\end{abstract}

Essa dinâmica de forças indica que não se trata de uma simples evocação de imagens anteriores, mas de representações, modelos anteriores que se interpõem no momento da produção da fotografia, da pintura, por exemplo, ou de sua circulação. Essas representações disponíveis e já familiares são metamor- 
foseadas em novas produções, desse modo uma imagem sempre se reporta a outra imagem, configurando um diálogo de imagens. Michaud (2013) destaca que há significações transversais entre as imagens, mesmo que essas sejam de natureza distinta (fotos, vídeos, pinturas, desenho). Contudo nem sempre destinamos tempo para a contemplação desse conjunto, observamos as imagens isoladamente, mas o seu processo de circulação não é finito, nem dissociável, principalmente quando tratamos de imagens totêmicas, ou seja, de imagens que se consolidam impedindo novas formas de compreensão. Se pensarmos nos conflitos do Oriente, certamente a imagem das crianças-vítimas será acionada e a cada nova imagem as anteriores se acoplam.

\section{A produção para a circulação e a adesão ao fantasma}

A partir da ideia de que há relações de dependência entre as várias formas de produção imagética e, neste caso, entre as fotografias em si, voltamos nosso olhar para a produção das imagens para a circulação. Ressalva-se que não se trata de pensar essa produção apenas no âmbito dos dispositivos midiáticos jornalísticos, mas especialmente nos espaços de atores sociais. Observa-se uma espécie de adesão ao fantasma, ou seja, ele se instala como uma sombra em discursos múltiplos, de múltiplas fontes. Estamos diante de uma imagem autorreferente, que reverbera. Barthes (1980, p. 138) já falava da questão da referência, para ele "os códigos vão influenciar a leitura da foto", uma vez que se configura como uma "emanação do real passado". Sem entrar na discussão sobre o real, interessa-nos aqui o aspecto da referência. Não temos como olhar uma fotografia sem os filtros que podem ser de ordem cultural, social, particular. Isso coaduna com a proposta de Warburg de que uma imagem sempre se reporta a outra precedente, mesmo que em suas ressignificações. Ou seja, quando falamos da circulação das imagens não estamos falando da perpetuação de sentidos únicos, mas da reinscrição de imagens iguais, ainda que tencionadas.

Quanto à referência, Umberto Eco (1974) destaca que as concepções sobre o referente, discutidas em termos semióticos, são muitas vezes equivocadas, pois confundem a referência com o objeto, ou ainda, que o significado tem obrigatoriamente a necessidade de vincular-se ao termo a que se refere. Esse equívoco para Eco é superado quando assume o significado como "unidade cultural". Para o autor (1974, p. 15) "toda a tentativa de estabelecermos o que seja o referente de um signo obriga-nos a definir esse referente em termos de uma entidade abstrata, a qual não passa de uma convenção cultural". Assim o significado de 
um termo é uma unidade cultural, portanto, unidades que permanecem invariáveis apesar dos símbolos com as quais as significamos ou entre línguas distintas. Isso implica em "sistemas de convenções que se explicam reciprocamente". Essa ressalva de Eco nos ajuda a pensar a referência explícita de uma fotografia em outra mesmo perante a sua ausência. Isto é, a referência não é dada pelo objeto em si, mas pela unidade cultural acionada. Além disso, as imagens que integram o corpus deste artigo são autorreferentes, uma vez que se descolam dos fatos a que se referem estendendo-se para além deles.

Desta forma, podemos entender que as imagens inseridas na circulação, integrantes desse intenso processo de midiatização social, sempre se referem a outras imagens, em uma espécie de circularidade infinita e se configurando em barreiras para outras possibilidades interpretativas. As imagens a seguir (Figura 5 e Figura 6) evidenciam essa relação entre imagens que é produzida de modo intermidiático, ou seja, tanto por chargistas em dispositivos midiáticos jornalísticos como por atores sociais midiatizados em suas páginas do Facebook. Revelam, ainda, que a autoria se perde no processo de circulação, pois os atores sociais se apropriam do que já está em circulação, em uma manifestação da fagia social, revalorizando as imagens.

Figura 5 - Charge criada por desenhista sudanês em agosto de 2016

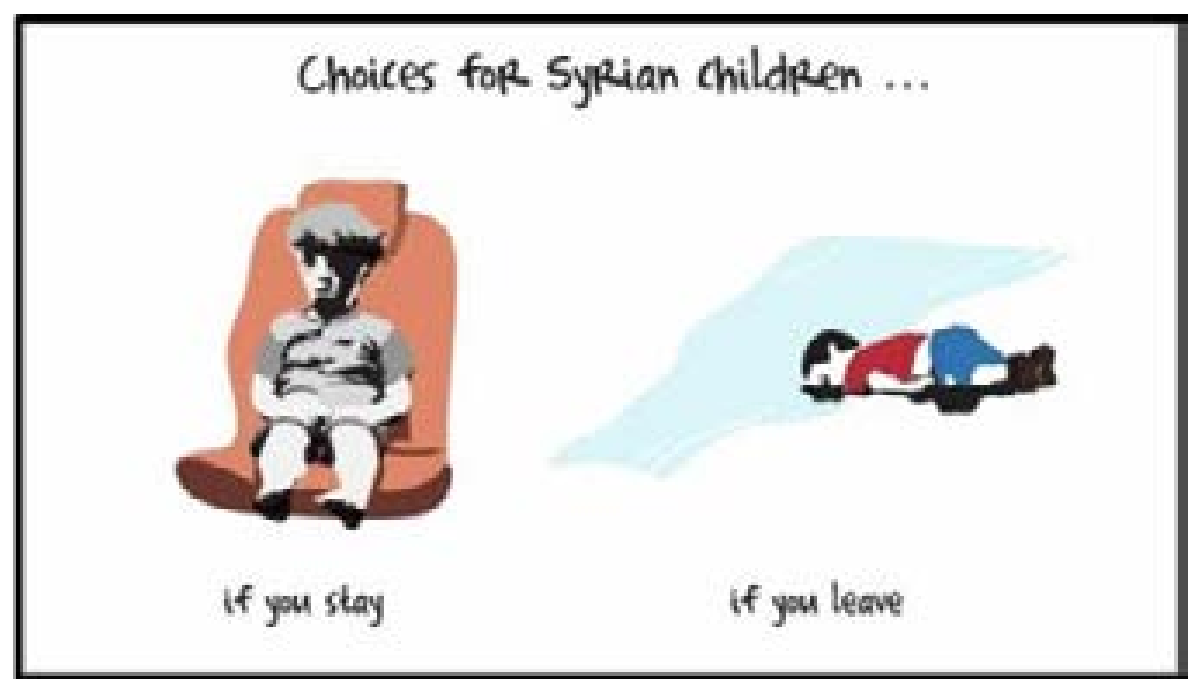

Fonte: Khalid Albaih. 


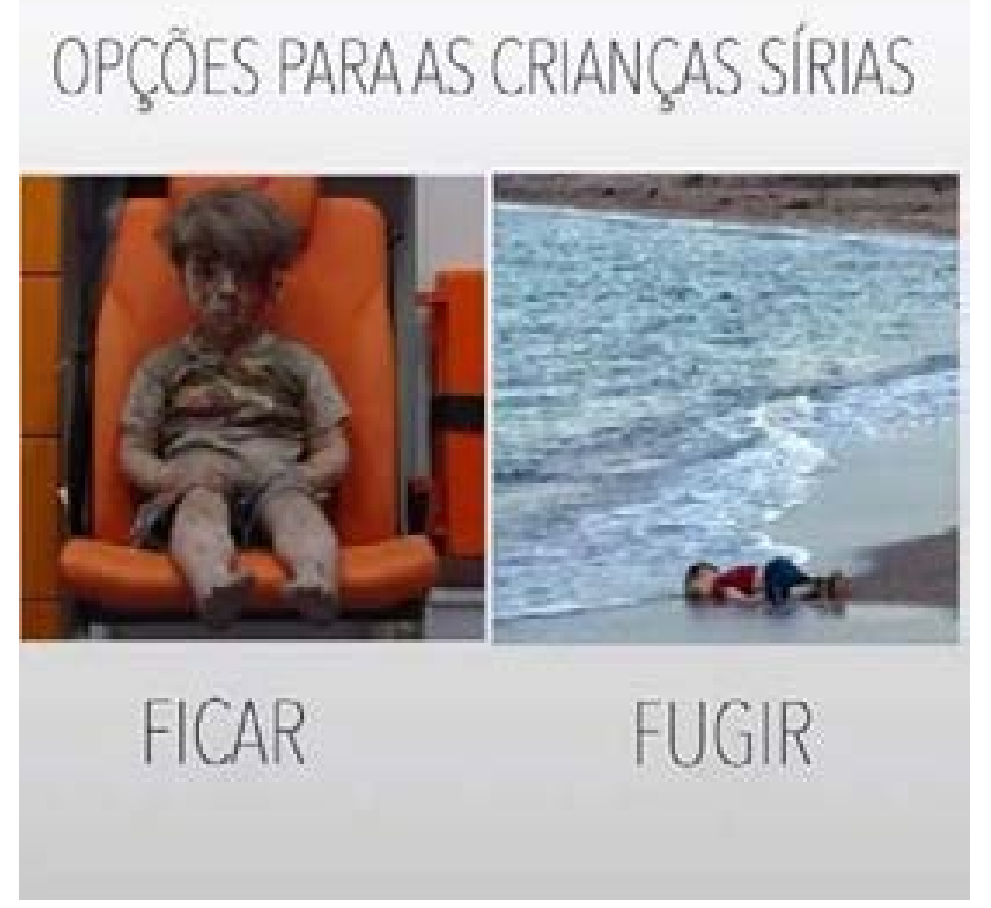

Fonte: Facebook Quebrando o Tabu.

Verifica-se na Figura 5 que a construção do chargista sudanês disponibilizada na rede social e posteriormente inserida em dispositivos jornalísticos produz uma relação explícita entre as imagens. A fotografia de Daqneesh é associada à de Aylan Kurdi, sendo que o processo rememorativo é acionado para abastecer um novo sentido: um alerta social quanto à situação das crianças sírias como um todo, retirando o caráter episódico da fotografia primeira. Os dois casos vinculados parecem antecipar novos casos envolvendo vítimas dos conflitos, a ponto de ser realizada uma comparação que sugere que a permanência na Síria implica em aceitar um estado de choque; já migrar para outro país implica em conviver com a iminência da morte. Assim, o chargista incita a reflexão quanto à falta de escolha. O desenho, embora simples, reproduz os elementos principais das imagens primeiras, as cores, as personagens, os ângulos aproximados e preserva o choque, ainda que amenizado.

Já na montagem da Figura 6, temos exatamente a mesma relação disponibilizada por meio de atores sociais em dispositivos midiáticos como páginas de Facebook. Não há nessa montagem nenhuma menção ao autor da charge anterior, mas a composição não deixa dúvida de sua característica de cópia. A 
diferença central está no modo de representação, feito a partir da junção das duas imagens primeiras enquanto fotografias. Neste caso não se trata apenas da referência às imagens que circularam anteriormente, mas de sua replicação efetiva. Pode-se dizer que o uso da fotografia acentua o aspecto do choque, que é amenizado na charge, mas em ambas as figuras temos claramente o movimento de aproximação das duas situações, a evocação de um fato anterior que é atualizado e que permite antever novas ocorrências.

Uma nova ocorrência é registrada de fato: o vídeo da menina Aya, que é semeIhante à fotografia de Daqneesh por exibir uma criança síria desesperada e com marcas da violência (o sangue em seu rosto) como se ela figurativizasse todas as vítimas. O vídeo feito por um grupo ativista foi produzido para a circulação, ou seja, para a visibilização coletiva. Trata-se de produzir a imagem com fins explícitos de inscrevê-la em dispositivos midiáticos para acionar o fluxo comunicativo, pois a partir da imagem da Aya há uma profusão de interações derivadas que remontam a outras imagens vistas anteriormente. Interessa-nos pensar, então, que as imagens que compõem o corpus deste artigo parecem manter certos padrões tanto plásticos como de significação. Essa mesma voluntarização para a circulação, portanto, para a valorização das imagens, ocorre no caso do bebê de Mianmar, desta vez de forma mais acentuada, pois a fotografia primeira é inscrita em um dispositivo midiático de um grupo ativista, mas sem obter a reverberação imaginada. A imagem só ganha o centro dos holofotes quando o pai da criança em questão se voluntaria para inscrevê-la na circulação, disponibilizando-a para instituições jornalísticas diversas e propiciando apropriações em espaços de atores sociais. Implica dizer que, nessa situação específica, o próprio afetado se configura em um ator social que agencia a circulação intermidiática vinculando a sua experiência com experiências anteriores já didatizadas pelos meios de comunicação, assim tal ator assume as lógicas midiáticas. A imagem do bebê de Mianmar passa a figurar como um duplo da imagem de Aylan Kurdi, isto é, a sua repetição não apenas como acontecimento, mas como imagem aderente. Estamos diante de movimentos de adesão ao fantasma.

\section{Considerações finais}

Ante o exposto, é possível apontar que as superfícies se consolidam no cenário da midiatização, não apenas porque estão disponíveis através e nos meios de comunicação, mas porque se instalam no tecido social, sendo constituintes das práticas coletivas. Assim, as imagens-superfícies nos cercam, mas também as 
cercamos, principalmente, quando nos voluntariamos para a sua produção e a sua circulação. Assume-se aqui a perspectiva de que a midiatização é, em essência, a complexificação das relações sociais e, consequentemente, da produção de sentido derivada. Se, de um lado, os atores sociais ascendem aos meios, de outro, os meios tradicionais, com ênfase para os jornalísticos, buscam realizar uma espécie de chancela do visível, derivando em uma disputa pelo que deve ser visto. O pressuposto aqui defendido é o de que as fotografias e vídeos convocam estruturas profundas do social, acionando as imagens interiores já consolidadas no social. Ao serem apresentadas na paisagem circulatória, passando por um processo de valorização, essas imagens se autonomizam, passando a se constituir nos próprios acontecimentos, de tal modo que a referência passa a ser a imagem socializada.

Essa, por sua vez, se torna referência para outras imagens posteriores, incitando um processo intenso de circularidade ou de abismo. Uma imagem consolidada socialmente, como a de Kurdi, não morre junto com o fato a que se reporta, a fotografia perdura porque está ancorada em códigos culturais e em convenções. Todavia essa imagem não perdura isenta de modificações, ao contrário: a sua vida póstuma (ou nachleben) está ancorada em suas transformações de sentido, nos fluxos derivados na circulação. Quanto mais a imagem reaparece, adere a novos casos e acontecimentos, mais força de permanência adquire, mesmo que possamos pensar em um desgaste natural. Tal desgaste acaba por ser diminuído com o jogo interacional, ou seja, as elaborações e reelaborações feitas tanto no âmbito jornalístico como de atores sociais revaloriza a imagem primeira. Recuperamos aqui o questionamento: a ressignificação das imagens mantém os sentidos originais? Em nosso caso de análise não se trata de uma ressignificação, mas de uma preservação da imagem primeira. O original é sempre atualizado, preservando os sentidos mais antigos e reescrevendo-os em fluxos adiante, mesmo quando em manifestações discordantes. Ora, isso não significa que a circulação dos sentidos seja uma diminuição das defasagens ou uma possibilidade de consenso, mas se configura como uma relação de atribuição de valor e de disputa pelo que deve ser visto.

E o que deve ser visto? A partir da análise e reflexão de nosso caso empírico temos dois pontos a ressaltar: 1) a questão da perda da corporeidade e a sua conformação às bordas da imagem, uma vez que é a imagem do corpo que permanece em circulação; e 2) a instalação da imagem como uma fantasmagoria. Quanto à perda da corporeidade vale destacar que cada vez mais são as imagens de cadáveres que nos lembram do corpo vivo, resultando em um sentir 
distante e mediado, em uma valorização do corpo morto, da foto-choque, do abalo aos olhos. Já quanto à fantasmagoria, percebe-se que a possibilidade de reaparição de uma imagem está associada a sua capacidade de permanecer em circulação, portanto, de ter traços retomados em imagens posteriores. A ideia de vida póstuma ou de nacheleben acentua o aspecto espectral, já que mesmo quando a fotografia primeira não é explicitada, sua sombra paira sendo fundamental acompanhar os sentidos produzidos também nos intervalos entre uma imagem e outra.

Para conviver com essas imagens dois caminhos se abrem: a adesão aos fantasmas ou a aceitação da necessidade de negociação, como aponta Baitello Júnior (2010). A fotografia de Kurdi é um exemplo do fantasma que adere a toda produção posterior que trata da crise Síria. Sua capacidade de assombração não está apenas na sua repetição enquanto imagem, mas na restrição que impõe quanto à própria compreensão dos acontecimentos, já que a imagem primeira impõe que outras imagens sejam produzidas para a circulação, não para a sua substituição.

\section{Referências}

ALBAIH, Khalid. Figura 5 - Charge criada em 2016. Disponível em: http://g1.globo.com/ mundo/noticia/2016/08/enquanto-voce-vive-sua-vida-essas-criancas-estao-morrendo-diz-autor-de-cartum-viral-sobre-menino-sirio.html. Acesso em: 15 jan. 2017.

BAITELLO JR., Norval. A serpente, a maçã e o holograma: esboços para uma Teoria da Mídia. São Paulo: Annablume, 2010. https://doi.org/10.31789/rpd-201808220030

BELTING, Hans. O fim da história da arte: uma revisão dez anos depois. São Paulo: Cosac Naify, 2006.

BRAGA, José Luiz. Circuitos versus Campus. In: JANOTTI JR, J; MATTOS, M A; JACKS, N. Mediação \& midiatização. Salvador: EDUFBA, Brasília COMPÓS, 2012. p. 31-52. https:// doi.org/10.7476/9788523212056

BRAGA, José Luiz et al. (org.). Dez Perguntas para a produção de conhecimento em comunicação. São Leopoldo: Unisinos, 2013.

DEMIR, Nulifer. Figura 1 - Fotografia reproduzida em múltiplos dispositivos. Disponível em: http://www.theguardian.com/world/2015/sep/02/shocking-image-of-drowned-syrian-boy-shows-tragic-plight-of-refugees. Acesso em: 20 abr. 2018.

DURAND, Gilbert. Imaginação simbólica. Lisboa: Edições 70, 1993. 
ECO, Umberto. As formas do conteúdo. São Paulo: Perspectiva, 1974.

FACEBOOK QUEBRANDO O TABU. Figura 6 - Opções para crianças sírias. Disponível em: http://www.facebook.com/quebrandootabu. Acesso em: 20 abr. 2018.

FACEBOOK RO SADAK. Figura 4 - Bebê de 16 meses. Disponível em: https://www. facebook.com/sadak777777//. Acesso em: 20 jan. 2017.

FELINTO, Erick. O espectro na sala de estar: as imagens e o imaginário tecnológico da fantasmagoria. In: ARAÚJO, Denize (org.). Imagem (ir) realidade: comunicação e cibermídia. Porto Alegre: Sulina, 2006.

FERREIRA, Jairo. Midiatização: dispositivos, processos sociais e de comunicação. Revista E-compós. v. 10, 2007. Disponível em: http://www.compos.org.br/seer/index.php/e-compos/article/viewFile/196/197. Acesso em: 20 ago. 2016. https://doi.org/10.30962/ $\underline{\text { ec.196 }}$

FERREIRA, Jairo; ROSA, Ana Paula da. Midiatização e poder: a construção de imagens na circulação intermidiática. In: TEMER, Ana Carolina Rocha Pessoa (org.). Mídia, cidadania \& poder. Goiânia: Facomb/FUNAPE, 2011.

FLUSSER, Vilém. O mundo codificado: por uma filosofia do design e da comunicação. São Paulo: Cosac Naify, 2007.

GOMES, Pedro Gilberto. Os processos midiáticos como objeto de estudo. In: Tópicos da Teoria da Comunicação. São Leopoldo: Unisinos, 2004.

KAMPER, Dietmar. Mudança de horizonte: o sol novo a cada dia. São Paulo: Paulus, 2016.

KLEIN, Alberto; ROSA, Ana Paula da. Atentado em imagens: sincronização e circularidade na mídia. Revista Grebh, n. 8, São Paulo: CISC, 2006. Disponível em: http://revista. cisc.org.br/ghrebh8/artigo.php?dir=artigos\&id=beto klein. Acesso em: 17 jan. 2016.

LEMOS, Anuschka. Um mergulho no abismo: estratégias comunicacionais da imagem fotográfica. Curitiba: UTP, 2007.

MICHAUD, Philippe Alain. Aby Warburg e a imagem em movimento. Rio de Janeiro: Contraponto, 2013.

RASLAN (Reuters). Figura 2 - Resgate na Síria. Disponível em: http://g1.globo.com/ mundo/noticia/2016/08/lagrimas-comecaram-cair-diz-autor-de-foto-do-menino-omran-na-siria.html. Acesso em: 20 jan. 2017.

ROSA, Ana Paula da. De reflexos a fagias: os níveis de circulação e apropriação midiática das imagens. In: CINGOLANI, Gaston; SZNAIDER, Beatriz. Nuevas mediatizaciones, nuevos públicos. Argentina, 2016. Rosario: UNR Editora. Editorial de la Universidad Nacional de Rosario, 2016a. https://doi.org/10.19137/anclajes-2013-1727 
ROSA, Ana Paula da. Imagens em proliferação: a circulação como espaço de valor. $V$ COLÓQUIO DE SEMIÓTICA DAS MÍDIAS. Anais... Japaratinga: UFAL, 2016b.

ROSA, Ana Paula da. Atentado em looping: uma palavra que aciona uma imagem. Revista Famecos, Porto Alegre, v. 22, n. 4, 2015. Disponível em: http://revistaseletronicas. pucrs.br/ojs/index.php/revistafamecos/article/view/20992. Acesso em: 20 jan. 2017.

TALBISEH Media Center. Figura 3 - Aya o novo o rosto. Disponível em: https://br.noticias.yahoo.com/aya-a-menina-que-se-transformou-no-novo-rosto-da-101136692.html. Acesso em: 10 jan. 2017. https://doi.org/10.15448/1980-3729.2015.4.20992

VERÓN, Eliseo. La semiosis social 2: ideas, momentos, interpretantes. Buenos Aires: Paidós, 2013.

VERÓN, Eliseo. Fragmentos de um tecido. São Leopoldo: Editora Unisinos, 2004.

WAIZBORT. Leopoldo. Apresentação. In: WALBURG, Aby. Histórias de fantasmas para gente grande: escritos, esboços e conferências. São Paulo: Companhia das Letras, 2015.

WARBURG, Aby. Histórias de fantasmas para gente grande: escritos, esboços e conferências. São Paulo: Companhia das Letras, 2015.

\section{Dados da autora:}

Ana Paula da Rosa - anarosa208@yahoo.com.br

Professora do Programa de Pós-Graduação em Ciências da Comunicação da Universidade do Vale do Rio dos Sinos (PPGCOM-Unisinos). Doutora em Ciências da Comunicação pela Unisinos e Mestra em Comunicação e Linguagens pela Universidade Tuiuti do Paraná.

\section{Endereço da autora:}

Unisinos, Programa de Pós-Graduação em Ciências da Comunicação Av. Unisinos, 950, Cristo Rei, 93.022-750 - São Leopoldo (RS) - Brasil 